日臨外医会誌 $58(12), 2891-2895,1997$

症例

腹膜中皮腫の播種性転移により小腸穿孔をきたした 1 例

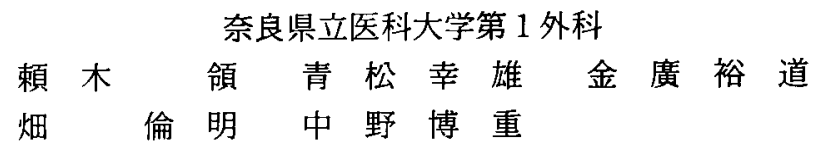

症例は64歳男性. 主訴は右下腹部痛. 石綿肺にて当院内科で加療されていたが, 右下 腹部痛出現し当科に紹介された。腹部に強い反跳痛を, 胸部 X 線写真にて free air を認 めたため, 消化管穿孔による腹膜炎と診断し, 緊急手術を施行した. 開腹時, 右横隔膜 を主病巣とする径 $5 \mathrm{~cm}$ 大の腫瘍を, また腹腔内に最大径 $2 \mathrm{~cm}$ 大の多数の播種性転移巣を 認めた。回腸末端より口側 $20 \mathrm{~cm}$ の部位の転移巣に穿孔を認め, この部位を含む回腸部分 切除術および端々吻合術を施行した。病理組織検査にて, 中心が壊死に陥り穿孔を起こ した腹膜中皮腫の播種性転移を認めた。コロイド鉄を用いた免疫組織化学染色にて中皮 腫との確診を得た。腹膜中皮腫は比較的稀な疾患であり, 播種性転移による小腸穿孔と いう興味深い症例を経験したので若干の文献的考察を加えて報告する.

索引用語：腹膜中皮腫, 汎発性腹膜炎, 小腸穿孔

\section{緒 言}

中皮腫は，体腔獎膜表面の被覆細胞に由来する腫漡 で, 胸膜・腹膜・心膜・精巣䩪膜に発生する比較的稀 な疾患である．腹膜中皮腫は臨床所見にそしく，術前 または生前に診断される症例は少ない.今回われわれ は腹膜中皮腫の播種性転移により小腸穿孔をきたした 症例を経験したので報告する。

$$
\text { 症例 }
$$

患者：64歳, 男性.

主訴: 右下腹部痛.

家族歴: 母, 子宮癌・胆䟠結石症.

既往歴: 33歳, 肺結核.

職業歴：21歳から60歳まで, 40 年間石綿加工製品の 品質管理に従事.

喫煙歴：19歳から60歳まで, 10本/日.

現病歴：1995年 7 月より, 石綿肺・強皮症の精査加 療目的にて当院第 2 内科入院中, 精査の結果, 腹腔内 腫湯・ネフローゼ症候群も診断された。8月10日右下 腹部痛が出現し, 症状軽快しないため, 8 月 15 日当科 紹介された。

現症：四肢の浮腫・前腕皮膚の硬化を認めた。両下 肺野に乾性ラ音を聴取した。右下腹部には強い圧痛・

1997年 4 月 18 日受付 1997 年 7 月 24 日採用
筋性防御・反跳痛を認めた. 腹部腫瘤は触知しなかっ た。

術前検査所見: WBC $7,600 / \mathrm{mm}^{3}, \mathrm{RBC} 362 \times 10^{4} /$ $\mathrm{mm}^{3}, \mathrm{Hb} 11.6 \mathrm{~g} / \mathrm{dl}$, Plt $62.1 \times 10^{4} / \mathrm{mm}^{3}$, T-Bil 0.2 $\mathrm{mg} / \mathrm{dl}$, GOT $19 \mathrm{IU} / l$, GPT $6 \mathrm{IU} / l$, BUN $28 \mathrm{mg} / \mathrm{dl}$, $\mathrm{CRE} 1.8 \mathrm{mg} / \mathrm{dl}, \mathrm{Na} 132 \mathrm{mEq} / l, \mathrm{~K} 5.9 \mathrm{mEq} / l, \mathrm{Cl} 99$ $\mathrm{mEq} / l, \mathrm{CRP} 6.3 \mathrm{mg} / \mathrm{dl}$ と, 賽血, 血小板增多, 炎症 所見, 腎機能障害を認めた. 腫瘍マーカーでは SCC 抗 原1.2ng/dl, AFP 2.9ng/ml, CEA 3.6ng/ml と正常 範囲内であったが, CA19-9 51.3U/ml, ヒアルロン酸 $89 \mathrm{ng} / \mathrm{ml}$ と上昇していた.

胸部 X 線検查所見：両下肺野に石綿肺による網状 影，両側横隔膜下に free air を認めた（図 1)。

腹部 CT 検査所見 (内科入院時) : 右横隔膜腹側に横 隔膜から発生したと考えられる $5 \mathrm{~cm}$ 大の腫瘤陰影を 認め, 肝を圧排していた. 腫瘤周囲には, 液貯留を認 めた（図 2 )。

腹部超音波検査所見：肝外に数個の hypoechoic mass が存在し肝を圧排していた，モリソン窝に少量 の腹水を認めた。

$\mathbf{G a}$ シンチ検查所見 (内科入院時) : 肝の右上方に強 い abnormal hot areaを認めた。

穿刺吸引細胞診 (内科入院時) : class V. 炎症細胞 に混在して中皮腫に近い細胞を散在性あるいは集塊で 


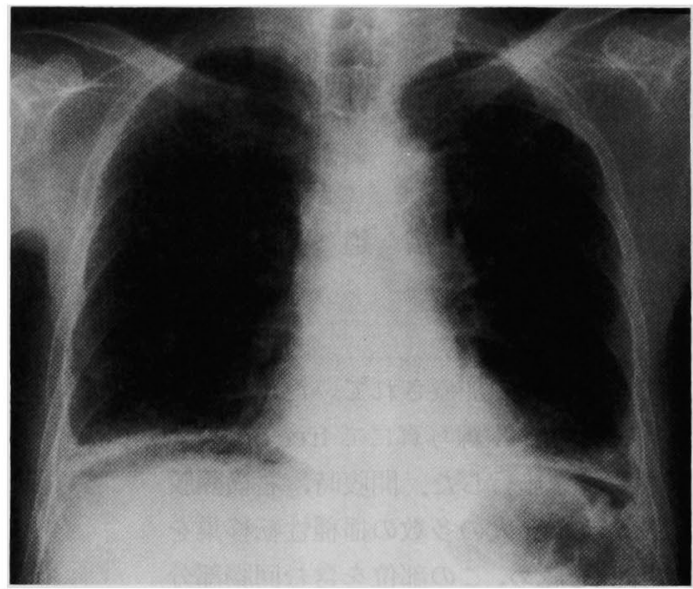

図 1 胸部単純 $\mathrm{X}$ 線正面像: 両下肺野に石綿肺によ る網状影，両側横隔膜下に free air 認めた。

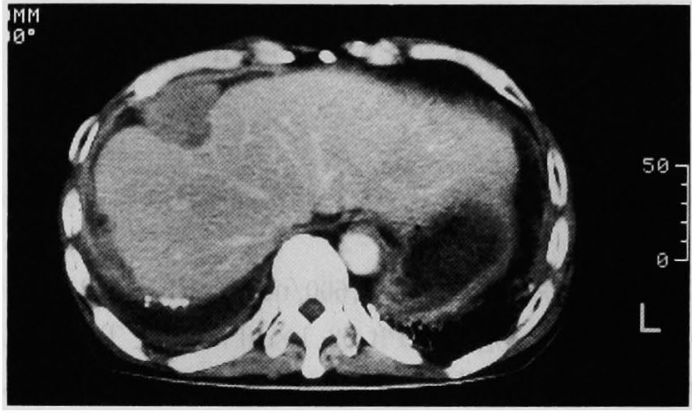

図 2 腹部 CT 検査 (内科入院時) : 右横隔膜下に横隔 膜から発生したと考えられる $5 \mathrm{~cm}$ 大の腫瘤陰影を 認め，肝を圧排していた。腫瘤周囲には液貯留像を 認めた。

認め，大型の多核細胞が混じっていた。

生検所見 (内科入院時)：HE 染色では，腫瘍は大小 不同を示す異型性の強い細胞の増生からなって抢り, 腺あるいは扁平上皮への分化は明らかではなかった。 免疫組織化学染色によりケラチンに強陽性, ビメンチ ンにも一部陽性で, ヒアルロン酸の産生は確認できな かったが上皮型の悪性中皮腫が最も考えられた。

当科紹介時の所見より消化管穿孔による沉発性腹膜 炎と診断し，8月15日緊急開腹術を施行した。

手術所見：開腹時, 黄白色・膿汁様の腹水が中等量 貯留していた。右横隔膜下に $5 \mathrm{~cm}$ 大の主腫瘤が, また 腹膜には，びまん性に大小の結節状腫留が存在してい た。回腸末端より $20 \mathrm{~cm}$ 口側に, $2 \mathrm{~cm}$ 大の腫瘤が漿膜側 に存在し、この部位に穿孔を認めた。この部位を含め
約 $10 \mathrm{~cm}$ の回腸を切除し, 端々吻合術を施行した.

切除標本所見：切除標本では腫瘤の大きさは $2.0 \times$ $1.5 \mathrm{~cm}$ であった. 白色調を呈し, その中心部は壊死に 陥って打り穿孔を認めた（図 3 ).

病理組織検査所見：HE 染色の弱拡大像では, 槳膜 側より粘膜下へ向かっての腫瘍細胞の増殖を認め，播 種性転移と診断した（図 4).

強拡大像では, 類円型・均一な細胞が充実性に増殖 している像を呈し，悪性中皮腫が疑われた（図 5).

術後経過：腹部症状は順調に改善したが, 石綿肺に よる呼吸症状増恶し, 術後37日目喀痰による気道閉塞 にて死亡した。

剖検所見：横隔膜下腫瘤も切除標本と同様の所見で あり，ヒアルロン酸の存在を確認するためにコロイド 鉄染色を行った．細胞質内にコロイド鉄染色陽性の物 質を認め，ヒアルロニダーゼ消化試験にて消化される ことにより, ヒアルロン酸であると断定, 悪性中皮腫 と診断した（図6）.

\section{考察}

中皮腫は, 胸膜 - 腹膜 - 心膜 - 精巣鞘膜といった, 体腔を覆う中皮細胞より発生する比較的稀な腫瘍であ

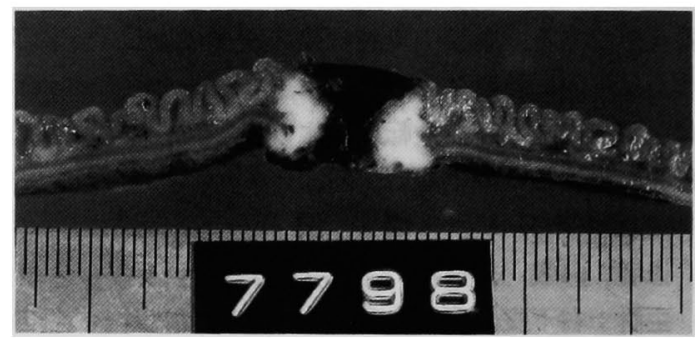

図 3 切除標本割面：腫瘤は $2.0 \times 1.5 \mathrm{~cm}$. 白色調を呈 し，その中心部は壊死しており穿孔を認めた。

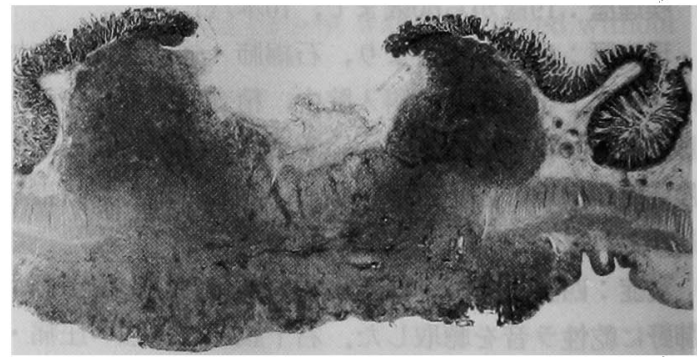

図 4 病理組織学的所見: 槳膜側より粘膜側へ向かっ ての腫瘍細胞の増殖を認めた(HE 染色, ルーペ像)。 
る.腹膜中皮腫は，中皮腫全体の約 $20 \%$ 占める ${ }^{11}$. 北 原ら ${ }^{2)}$ が報告した240例では，平均年齢は53.8歳であ り，男女比は $4 ： 3$ とやや男性に多い.

1960年 Wagner ${ }^{3)}$ が石綿粉塺曝露と中皮腫の発生と の因果関係を報告して以来，わが国においても石綿粉 塵曝露が社会問題となっている，中皮腫が発生した患 者の石綿粉塵吸入期間は，一般に平均 30 年ないし 40 年

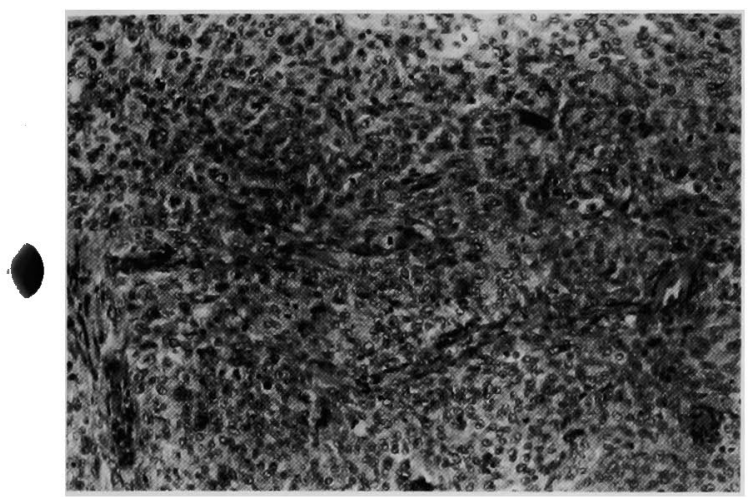

図 5 病理組織学的所見：類円型・均一な細胞が充実 性に増殖している像を呈し, 悪性中皮腫が疑われた (HE 染色, $\times 200)$.
といわれる。わが国での石綿の使用は第二次世界大戦 以後であり, 今後も中皮腫の発生が増加してくること が考えられる ${ }^{4)}$. 本例では40年間の石綿粉塵曝露歴が あり，石綿が腫瘍発生に関与していた可能性が強いと 考えられる。一般に胸膜中皮腫は環境污染などによる 低濃度曝露者に多く，腹膜中皮腫は職業的な高濃度曝 露者に多いとされる5). 石綿が腹腔内に到達する経路 については種々の異論があるが, 嚥下された石綿が消 化管壁を貫通して腹腔内に入るとする意見や, 肺に吸 入された石綿がリンパ経由に腹膜に到達するという意 見が一般的である ${ }^{6}$. しかし本例では, 肺には石綿小体 を認めたが，腹腔内に石綿小体を認めることはできな かった。

臨床症状としては, 腹部膨満, 腹痛, 腹部腫瘤, 食 思不振，発熱，下痢，便秘といったものがある。しか しながら, 特有の症状というものはなく, 本症の診断 を困難にしている原因の一つとなっている。また腹水 を伴う例が多く, 癌性腹膜炎との鑑別が問題となる. 腹水細胞診を行っても正診率は低い2)7).この理由は, 腹水細胞診上の多彩な細胞所見が，覀性中皮腫と反応 性中皮細胞や癌細胞との鑑別を困難にしている場合が 多いためとされている。また, 腹部超音波検査や腹部
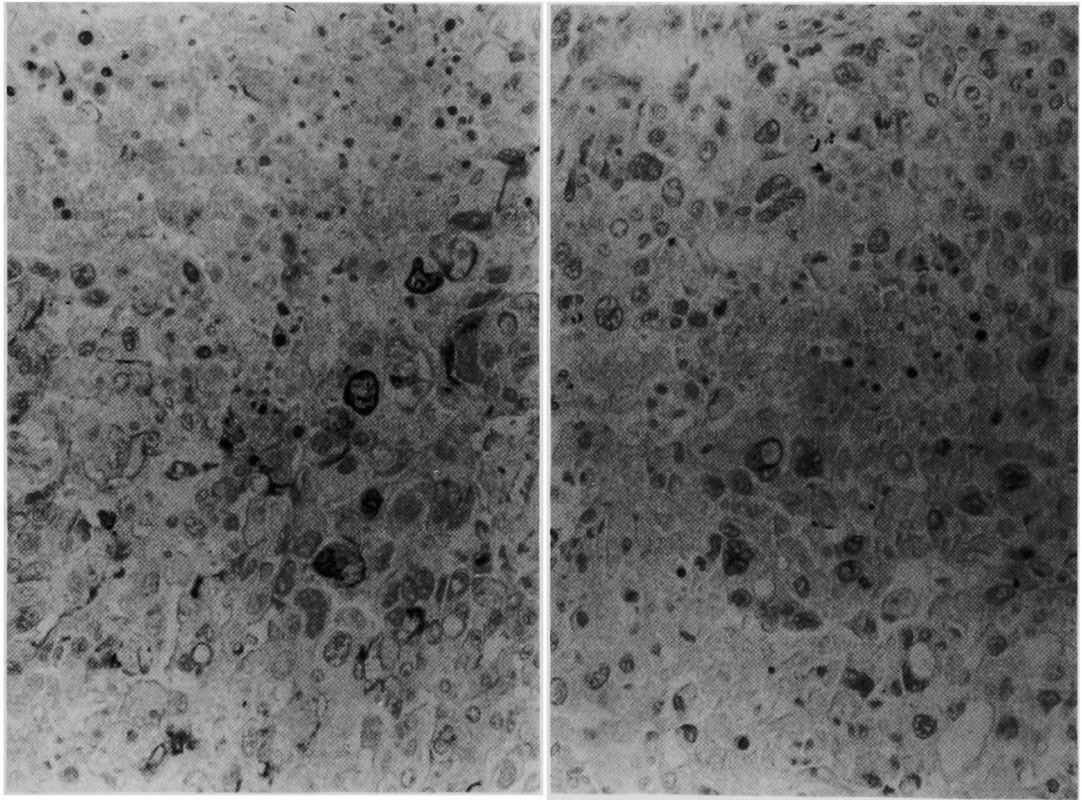

図 6 免疫組織化学的所見：剖検で得られた右横隔膜下腫瘤はコロイド鉄染色により 細胞質内にコロイド鉄染色陽性の物質を認めた (左)。この物質はヒアルロニダーゼ にて消化され，ヒアルロン酸であると証明された（右）。 
$\mathrm{CT}$ 検査では多彩な腫瘤像を呈するため，他の腫瘤と の鑑別が困難である.

中皮腫は，肉眼的には，限局型とびまん型の 2 型に， 組織学的には, 上皮型 (epithelial type), 混合型 (mixed type)，肉腫型 (sarcomatous type）の 3 型に分類され る. 組織学的に,びまん性に広がる転移性癌や肉腫と の鑑別，特に頻度の高い上皮性中皮腫と腺癌との鑑別 は非常に難しいとされる。これまでの報告でも，術前 または生前に中皮腫と䛦断された例は少なく，北原 ら あった。

予後は悪性では非常に不良で，急激な経過にて診断 後 1 年以内に死亡する例がほとんどである.

悪性腹膜中皮腫の蔵器内への浸潤は腸管ではしばし ば認められるが，槳膜層にとどまるものが多いとされ る。しかし佐々木ら ${ }^{8}$ の報告では 7 例中 1 例は粘膜下 まで著明な浸潤が認められたという。また Asensio ら9の報告では粘膜または粘膜下まで浸潤していたも のが28例中 9 例に認められている，ただこれらの中で も穿孔をきたした例は無い．わ机われが検索し得た限 り本邦において中皮腫が消化管穿孔をきたした例は無 く，本例は非常に稀な症例であったと考えられる。

悪性腹膜中皮腫は開腹時には広範に進展しているも のが多く外科的切除が困難な例が多い，化学療法につ いては, Cisplatin, Adriamycin, Mitomycin C 等の 腹腔内あるいは静脈内への投与により長期生存を得た とする報告もあるが，ほとんどが一時的に症状を軽減 させるにすぎない10111．以上の理由から外科的にも内 科的にも有効とされる治療が確立されていないのが現 状である。

これまで外科的治療についての報告は限局型に対す る根治的切除に関するものがほとんどであり，びまん 型に対する手術適応はないとされている。

本例では腹膜中皮腫が消化管穿孔をきたし，緊急開 腹術を施行し救命し得た. 腹膜中皮腫が消化管穿孔を きたすのは非常に稀であるが，その可能性も考えて迅
速な対応が必要である。

\section{結 語}

腹膜中皮腫の播種性転移によって消化管穿孔性腹膜 炎を発症した症例を経験したので, 若干の文献的考察 を加えて報告した。

本論文の要旨は1996年 2 月, 第64回日本消化器病学会近 畿支部例会において発表した。

\section{文献}

1）中野秀貴，乃能健一，赤羽弘充他：大網原発覀性腹 膜中皮腫の 1 例。臨外 $49: 121-124,1994$

2）北原健志，尾上謙三，高田美奈子他：腹膜恶性中皮 腫の 1 例と本邦報告例の検討. 日臨外医会誌 54 ： 1659-1663, 1993

3) Wagner JC, Sleggs CA, Marchand P: Diffuse pleural mesothelioma and asbestos exposure in the North-West Cape Province. Br J Industr Med 17:260--271, 1960

4）佐々木正道：石綿と肺。日赤医 $38: 1-15,1986$

5）緒見里秀和, 島袋国定, 大兼 剛他：噻胞状腹膜中 皮腫の 1 例。画像診断 $14: 1066-1070,1994$

6）佐藤鍊一郎, 師岡 長, 横山治夫他：悪性腹膜中皮 腫の 2 症例における石綿曝露の検討．消外 15 ： 1665-1672, 1992

7）仲 紘嗣，仲 綾子：日本における腹膜中皮腫の 臨床報告 100 例に関する臨床病理学的検討. 癌の臨 $30: 1-10,1984$

8）佐々木正道：覀性中皮腫の病理。病理と臨 7: 709-719, 1989

9) Asensio JA, Gold P, Thomford NR: Primary Malignant Peritoneal Mesothelioma. Arch Surg $125: 1477-1481,1990$

10）三原直子, 蜂須賀徽, 山崎実好他：化学療法によく 反応した悪性腹膜中皮腫の 1 例。癌の臨 33 ： 1939-1944, 1987

11）林 俊秀, 那須保友, 荒巻謙二他：MMC の腹腔内 注入およびUFT 内服により腹水の完全消失をみ た腹膜複製中皮腫の 1 例. 癌と化療 $16 ： 2449-$ 2452,1989 


\title{
A CASE OF PERITONEAL MESOTHELIOMA WITH SMALL INTESTINAL PERFORATION DUE TO DISSEMINATION
}

\author{
Ryo YORIKI, Yukio AOMATSU, Hiromichi KANEHIRO, \\ Michiaki HATA and Hiroshige NAKANO \\ First Department of Surgery, Nara Medical University
}

We report a case of peritoneal mesothelioma with small intestinal perforation. The patient was a 64-year-old man admitted to our department because of right lower abdominal pain. Previously, he had been diagnosed as having asbestosis. The patient had rebound tenderness on physical examination and free air shadow under the bilateral diaphragma was revealed by chest X-ray examination. We performed emergency laparotomy under a tentative diagnosis of generalized peritonitis due to intestinal perforation. We detected a $5 \mathrm{~cm}$ primary tumor under the right diaphragm, the peritoneum showed extensively scattered numerous nodules less than $2 \mathrm{~cm}$, and a perforating metastatic tumor on the ileum located 20 $\mathrm{cm}$ from Bauhin's valve. We performed partial resection of the ileum and reconstruction by end-to-end anastomosis. Postoperative histopathological findings revealed that the tumor of the ileum was a peritoneal mesothelioma and the central necrosis in the tumor was perforated. Histological confirmation can be achieved by immunohistochemical study with colloid-Fe. Perforated small intestinal tumor leading to peritoneal dissemination of mesothelioma is not a common disease. However, it should be taken into consideration in the differential diagnosis of other diseases caused by generalized peritonitis. 